УДК 37.091.12:005.963-022.33

DOI: $10.24144 / 2524-0609.2021 .49 .140-144$

\author{
Палько Тетяна Василівна \\ кандидат психологічних наук \\ доцент кафедри педагогіки та психології \\ Закарпатський інститут післядипломної педагогічної освіти \\ м.Ужгород, Україна \\ tanya0106.1967@ukr.net \\ http://orcid.org/0000-0003-2273-1472

\section{БЕЗПЕРЕРВНИЙ ПРОФЕСІЙНИЙ РОЗВИТОК - ШЛЯХ САМОРЕФЕРЕНЦІЇ ІДЕНТИЧНОСТІ ПЕДАГОГА}

\begin{abstract}
Анотація. У статті розкрито нові можливості творчої самореалізації та самовдосконалення педагога в умовах освітньої реформи із застосуванням Рамки безперервного професійного вдосконалення вчителів. Актуальність цієї теми викликана пошуком механізмів саморефлексії, самоактуалізації, саморозвитку педагога. До цього спонукає Рамка безперервного професійного вдосконалення, яка $є$ орієнтиром для створення інноваційних моделей професійного розвитку вчителів. Метою статті є розкриття нових можливостей творчої самореалізації та самовдосконалення педагога в умовах освітньої реформи із застосуванням Рамки безперервного професійного вдосконалення вчителів. Нами застосовано аналіз наукових розробок та нормативних джерел 3 проблеми безперервного професійного розвитку педагога, психолого-педагогічної, навчально-методичної літератури, інформаційних джерел з проблеми дослідження. У результаті дослідження нами було констатовано, що підтримка безперервного професійного розвитку педагога із застосуванням Рамки безперервного професійного вдосконалення вчителів $є$ ефективним інструментом для рефлексивного аналізу та реконструкції свого професійного шляху, а відтак - необхідною умовою професійного зростання, тому розвиток умінь підвищення власної мотивації, самоорганізації, усвідомлення вчителем його професійної ролі як фасилітатора учіння є важливою складовою дорожньої карти професійного розвитку педагога. Вмотивований педагог, користуючись Рамкою безперервного вдосконалення вчителів, може передбачити і спроєктувати траєкторію свого зростання, успіхів у педагогічній діяльності, можливостей і перешкод у досягненні цілей - професійного розвитку.
\end{abstract}

Ключові слова: рамка безперервного професійного вдосконалення вчителів; самореференція; дескриптор; фасилітатор; евалюація.

Актуальність проблеми. Професія вчителя $є$ однією з найбільш давніх, найбільш шанованих, найбільш почесних та найбільш відповідальних професій. «Незабаром виповниться 2 тисячоліття від того часу, як римський імператор і сенат (у I ст. до н.е.) почали видавати платню першому «штатному» вчителеві ораторів Марку Фабію Квінтіліану, що засвідчило появу вчительської професії» [1]. За тисячоліття багато чого змінилося, починаючи від умов праці до забезпечення свободи вчителю, «...включаючи свободу викладання, свободу від втручання в педагогічну, науково-педагогічну та наукову діяльність, вільним вибором форм, методів і засобів навчання, що відповідають освітній програмі, розробленням та впровадженням авторських навчальних програм, проєктів, освітніх методик і технологій, методів і засобів, насамперед методик компетентнісного навчання, право на вільний вибір освітніх програм, форм навчання, закладів освіти, установ і організацій, інших суб'єктів освітньої діяльності, що здійснюють підвищення кваліфікації та перепідготовку педагогічних працівників» [2]. Але ми повинні розуміти, що така свобода вимагає від педагога величезної відповідальності за кінцевий результат.

У більшості людей, не пов'язаних із системою освіти часто складається враження, що професія вчителя зосереджена тільки на проведенні уроків, але це $50 \%$, якщо не $30 \%$, того, що педагог робить у закладі освіти. Ще він готується до уроків, веде журнали, перевіряє зошити, диктує та виправляє диктанти, проводить та перевіряє тести, контрольні, лабораторні і практичні роботи; пише звіти, бере участь у роботі педрад, нарад, методичних об'єднань, проводить батьківські збори і невпинно відповідає на сотні дитячих запитань; намагається порозумітися зі здобувачами освіти та зацікавити їх своїм предметом. Учи- телі вчаться разом зі своїми учнями відповідати на потреби сучасності. Здобувачі освіти не зможуть зрозуміти необхідності навчатися протягом усього життя, якщо не візьмуть приклад зі своїх вчителів, тому педагог повинен випереджувати учня, а не йти 3 ним поруч. Відтак, перед учителем постає питання розвитку власної траєкторії професійного розвитку, яка б забезпечила безперервне оволодіння прогресивними технологіями навчання й виховання, розуміння і використання основ педагогіки й психології 3 метою розв'язання складних професійно-педагогічних проблем; інтеграції знань, практичних умінь і навичок із суміжних з педагогікою наук; активне та раціональне використання інформаційних технологій в освітньому процесі. Всі зазначені вище проблеми, які виникають у процесі досягнення професіоналізму вимагають від педагога пошуку дієвих шляхів підвищення свого фахового рівня.

Аналіз останніх досліджень і публікацій. Професійний розвиток - це розвиток людини в іiї професійній ролі. За визначенням американського науковця А.Глетсорна, професійний розвиток педагога розглядається як зростання його професійних досягнень в результаті накопичення практичного досвіду і систематичного перегляду власного викладання i отримується вчителем шляхом наставництва, відвідування професійних семінарів, майстерень тощо, a також неформальний досвід, такий, як читання професійної літератури, перегляд педагогічних передач та ін. [3, с.41]. Міжнародна група дослідників (Б.Авалос, Р.Болам, П.Хрісті, М.Дадс, Х.Дей, Дж.Елліотт, С.Граундвотер-Сміт, С.Граді, К.Харлеу, А.Харріс, Г.Келчтерманс, Г.Ліндсей, Ф.МакМахон, Д.Мюїджис, А.Пенні, Дж.Робінсон, Дж.Сакса, С.Шугруе, В.Тріпп, Дж.Літтл), вивчаючи питання неперервного професійного розвитку вчителів, опу- 
блікувала «Міжнародний підручник з неперервного професійного розвитку вчителів» [4]. Один 3 цих дослідників, англійський науковець С. Дей запропонував визначення професійного розвитку: «Це процес, у ході якого вчитель самостійно або разом зі своїми колегами переглядає, оновлює, розширює свої зобов'язання щодо моральної мети викладання, а також критично розвиває знання, вміння, хороше професійне мислення, планування і практику роботи 3 дітьми, молоддю й колегами на кожному етапі свого професійного життя» [5, с.4].

Проблема професійного розвитку педагогів $\epsilon$ актуальною в Україні, іiі дослідженню присвятили свої роботи Л.Банашко, В.Бондар, М.Войцехівський, О.Глузман, М.Заброцький, О.Просіна, О.Садовець, В.Химинець. Професор В.Семиченко розглядає професійний розвиток як усвідомлення та позитивне реконструювання життєвого і професійного досвіду [6].

Стосовно питання самореференції, то найбільш грунтовно з українських науковців його розкриває О.Ф.Яцина, яка розглядає самореференцію як самопредставлення ідентичності, сконструйоване за допомогою операцій самовизначення, самопізнання, самотворення, самовідтворення i самоздійснення у значущих комунікативних ситуаціях та як спосіб самовираження своєї індивідуальності, підгрунтям якого є інтерес суб'єкта до діяльності. Причому, О.Ф.Яцина висловлює думку щодо самореферентного утворення як доповненого представлення ідентичності $[7$, с.770].

Отже, однозначності у поглядах на цю проблему немає, але аналіз наукової літератури надав можливість зробити висновок, що професійний розвиток як складова самореференції педагога являє собою інтегральне поняття - процес, упродовж якого педагог на основі власного досвіду та рефлексивного аналізу реконструює свій професійний шлях.

Мета статті: розкрити нові можливості творчої самореалізації та самовдосконалення педагога в умовах освітньої реформи із застосуванням Рамки безперервного професійного вдосконалення вчителів.

Методи дослідження. 3 метою визначення нових можливостей творчої самореалізації та самовдосконалення педагога в умовах освітньої реформи застосовано аналіз наукових розробок та нормативних джерел з проблеми безперервного професійного розвитку педагога, психолого-педагогічної, навчально-методичної літератури, інформаційних джерел 3 проблеми дослідження, а також практичної діяльності у процесі підвищення кваліфікації педагогічних працівників на базі Закарпатського інституту післядипломної педагогічної освіти.

Виклад основного матеріалу. Освіта - це єдина галузь, у якій проводиться невпинне реформування такі зміни вимагають від педагога виконання нових завдань, які грунтуються на основних принципах педагогіки партнерства, серед яких: повага до особистості, доброзичливість і позитивне ставлення, конструктивний діалог, право вибору та відповідальність за нього тошо.

Нові ролі педагога реалізуються і в зміні знаннєвої парадигми на компетентнісну, що вимагає оволодіння раціональними прийомами розумової діяльності, формування інтелектуальних умінь, що можливо за умов, якщо до змісту інтелектуального сприйняття увійдуть проблеми і задачі практичного характеру, які будуть стимулювати здобувачів освіти до творчого мислення.

Отже, суспільство вимагає від педагога виконання нових ролей, і ці ролі вже увійшли у наше життя - коуча, фасилітатора, модератора, ментора i т.і.. Всі ці ролі розглянуті у Професійному стандарті вчителя, де також передбачено володіння вчителем, як професійних компетентностей, так і загальних, це i компетентність педагогічного партнерства, інформаційно-цифрова, проєктувальна, здатність до навчання впродовж життя; рефлексивна, громадянська компетентність; соціальна компетентність; культура самовираження; лідерська компетентність та інші[8].

Розглядаючи професійні стандарти педагогічних працівників звертаємо увагу на складові , які вже розроблені спільним проєктом Міністерства освіти i науки України та Британської Ради - Рамка безперервного професійного вдосконалення вчителів (далі - Рамка). Ії місія полягає в усвідомленні вчителем його професійної ролі як фасилітатора учіння (фасилітатор - «одна із ролей вчителя, яка полягає у створенні сприятливих умов для ефективного учіння, стимулюванні спільної діяльності учнів та спрямуванні процесу самостійного пошуку інформації» [9]).

У Рамці професійна діяльність учителів аналізується за дескрипторами відповідної категорії та дескрипторами всіх попередніх категорій. Рамка $\epsilon$ універсальною за своїм характером і може використовуватися вчителями усіх предметів [9].

Згідно з Рамкою відбувається заміна зовнішньої мотивації навчання внутрішньою, що органічно поєднує особистісний і професійний розвиток, орієнтує педагога на самопізнання, самоусвідомлення, самовдосконалення через рефлексію професійної діяльності та її ролі в житті педагога. У результаті такого аналізу приходить розуміння, що основна функція педагога полягає не в тому, щоб дати певну суму знань учням, яку здобував учитель упродовж всього життя, а навчити здобувачів освіти умінню вчитися, віднаходити нові знання, керуючись дорожньою картою, розробленою педагогом та мотивацією до процесу учіння. Отже, навчити навчатися - це те, на що потрібно спрямовувати педагогу основну увагу здобувача освіти, не стільки на засвоєння певних знань, скільки на засвоєння способів добування нової інформації, формування здатності конструктивно взаємодіяти 3 іншими людьми, підвищити адаптивні можливості учнів з метою забезпечення успішної інтеграції у спільноту як на наступних етапах навчання, так і при інтеграції у професійне середовище, сформувати потребу у самопізнанні, самоаналізі, неперервному саморозвиткові і т.і. На цьому акцентує увагу професор Химинець В.: «Сучасна освіта, окрім надання знань, має прищепити молодій людині здатність самостійно засвоювати знання, оволодівати потрібною інформацією та творчо осмислювати іiі» [10].

Сьогодні, особливо це можна відзначити під час оголошення карантину, вчитель повинен виконувати зовсім нові ролі - тьютора, фасилітатора, модератора, коуча, ментора, супервізора тощо. Для того, щоб опанувати всі ці нові ролі, а відтак відповідати запитам учасників освітнього процесу вчитель постійно повинен займатися самовдосконаленням, саморозвитком. Учитель - це постійний учень. Він оволодіває новими методиками, новітніми технологіями навчання й вибудовує свою власну професійну траєкторію. I саме зараз на часі став нещодавно затверджений Професійний стандарт вчителя, який розкриває нові професійні ролі і завдання педагога.

Під час проведення онлайн-вебінара «Нові професійні ролі і завдання педагога в контексті сучасних змін», виконуючи вправу «Рефлексія ролі педагога» на платформі Mentimeter слухачі курсів підвищення кваліфікації надають перевагу у своїй професійній діяльності виконанню ролі педагога-фасилітатора. Результати представлені у вигляді діаграми (рис.1) 


\section{Проранжуйте подані нижче ролі педагога за ступенем їх значущості для Вас особисто}

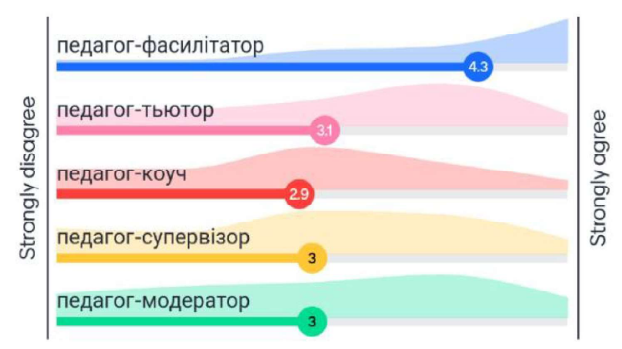

Рис.1 Скріншот стільниці під час проведення вправи

«Рефлексія ролі педагога» на платформі Mentimeter

Як бачимо на діаграмі, у більшості вчителі вказують на важливість у їхній професійній діяльності ролі педагога-фасилітатора, та педагога-тьютора. Ці дві ролі найбільше реалізуються в освітньому процесі сучасного закладу освіти. Роль педагога-фасилітатора полягає у супроводі здобувачів освіти в їхньому особистому розвитку. Щодо ролі педагога-тьютора, то це - ключова фігура в дистанційному навчанні. Звичайно, у той час, коли дистанційне навчання вчителів, як і учнів, тільки набирає обертів і ми ще не маємо результатів їхнього самостійного навчання, чи навчання під керівництвом тьютора, зарано говорити про повне усвідомлення власної професійної діяльності, iї впливу на подальший розвиток.

Постає питання, яким чином педагог буде досягати певних вершин: самостійно навчаючись, перебуваючи на дистанційному навчанні під керівництвом тьютора чи здобуваючи знання, практичні навички під час очного навчання у закладі післядипломної педагогічної освіти?

Рамка безперервного професійного вдосконалення спонукає вчителя саме до саморозвитку, незалежно від місця, шляхів, механізмів рефлексії, самоактуалізації, самозростання. Педагог, здійснюючи рефлексію власної професійної діяльності за відповідними дескрипторами визначає професійні потреби для вибору змісту, видів та форм післядипломної освіти, планує власний професійний розвиток та здійснення самоосвітньої діяльності. У ракурci професійного розвитку важливим є етап евалюації (евалюація - від англ. evaluation - оцінювання, «процес, який забезпечує розуміння та порівняння навчальних досягнень учня» [9]), а саме: діагностика та узагальнення помилок і труднощів учнів, допомога учням зрозуміти свої помилки та знайти шляхи їх усунення, розвиток у здобувачів освіти здатності до самооцінювання їхнього прогресу та навчальних досягнень із застосуванням тверджень «Я знаю», «Я умію», «Я можу», аналіз навчальних досягнень учнів та використання результатів аналізу для подальшого планування, аналіз впливу різноманітних підходів та стратегій оцінювання на процес учіння, дослідження власної діяльності та діяльності учнів на уроці задля розуміння та пошуку ефективних інструментів оцінювання.

У дескрипторі «Керування власним професійним розвитком» для вчителя, який тільки розпочинає свою педагогічну діяльність передбачено наступне: розуміє принципи рефлексії; співпрацює з колегами, постійно обмінюючись досвідом та ідеями, а також отримує підтримку від них; продовжує і далі навчатись; слідкує за останніми подіями в галузі освіти, бере участь у заходах, що сприяють професійному розвитку; володіє сучасними методиками аналізу уроку та використовує досвід колег у своїй діяльності; визначає аспекти професійного удосконалення, цілі та шляхи їх реалізації; розвиває власну навчальну автономію. Для вчителя з другою кваліфікаційною категорією цей дескриптор пропонує визначення цілей та планування свого професійного розвитку для досягнення поставленої мети; удосконалення фахової майстерності шляхом рефлексії; участь у взаємовідвідуванні задля власного професійного розвитку; постійне поновлення своїх фахових знань; обмін 3 колегами досвідом і думками у різних сферах професійної діяльності.

Прослідковуючи динаміку професійного зростання педагог бачить перспективу свого розвитку, оскільки у дескрипторі для вчителя 3 першою кваліфікаційною категорією передбачено вже чіткі цілі щодо професійного розвитку та пошук шляхів досягнення цих цілей. Такий педагог слугує прикладом професійної майстерності для інших учителів як у якості викладання, так і в здатності до безперервного навчання; оцінює новації в галузі освіти на основі власного досвіду та адаптує ідеї відповідно до власного розуміння ефективної навчальної діяльності; робить внесок у розвиток професії шляхом написання статей, розроблення навчальних матеріалів, проведення практичних семінарів, участі у фахових форумах або мережах.

Що ж до керування професійним розвитком вчителя з вищою кваліфікаційною категорією та тим, хто має педагогічне звання «старший учитель», то такому педагогу властиво все, перелічене вище для кожної кваліфікаційної категорії, але на додачу він бере участь у програмах і проєктах післядипломної освіти; у конкурсах фахової майстерності; у діяльності вчительської спільноти за межами свого закладу освіти; розвиває уміння в галузі онлайн освіти; підтримує кар'єру викладача-тренера та розвиває впевненість в цій ролі; модерує дистанційні (онлайн) курси.

Учитель, якому присвоєно звання «учитель-методист» додатково тренує та наставляє вчителів, допомагає у їхньому професійному розвитку; заохочує вчителів до рефлексії та оцінки власної діяльності; розробляє авторські програми та курси; залучений до проведення навчальних занять в закладі післядипломної педагогічної освіти, та педагогічної практики на базі свого закладу; веде дослідження в галузі освіти вчителів та застосовує результати на практиці; здійснює освітні проєкти; створює та керує освітніми мережами; веде семінари з фахового удосконалення.

Проведений аналіз наукової літератури, інформаційних джерел 3 проблеми дослідження свідчить, що самореференція набуває особливого значення для педагогів усіх рівнів від починаючого вчителя, який 
тільки обрав цю професію і до творчого професіонала. Соціальні та інформаційні трансформації змінили акценти в діяльності педагога з позиції функціонального виконавця на творчого реалізатора. В умовах змін педагог набуває здатностей до сприйняття нових ідей та їх реалізації в інноваційних процесах нових видів і форм навчання, враховуючи ситуацію, яка склалася в останні місяці в глобалізованому світі через COVID-19. Учитель опинився сам-на-сам з проблемою забезпечення якісного освітнього процесу дистанційно. У цих умовах педагог більш глибоко почав задумуватися над своїм власним «Я», самовдосконаленням, саморозвитком, вивченням професійної компетентності і т.і., оскільки педагог також повинен був навчатися.

Висновки та перспективи подальших досліджень. Таким чином, вмотивований педагог, користуючись Рамкою безперервного вдосконалення вчи- телів, може передбачити і спроєктувати траєкторію свого зростання, успіхів у педагогічній діяльності, можливостей і перешкод у досягненні цілей - професійного розвитку. Підтримка безперервного професійного розвитку педагога із застосуванням Рамки безперервного професійного вдосконалення вчителів $\epsilon$ ефективним інструментом для рефлексивного аналізу та реконструкції свого професійного шляху, а відтак - необхідною умовою професійного зростання, тому розвиток умінь підвищення власної мотивації, самоорганізації, усвідомлення вчителем його професійної ролі як фасилітатора учіння є важливою складовою дорожньої карти професійного розвитку педагога. Перспективи подальших досліджень полягають у створенні інформаційного дидактичного ресурсу для слухачів післядипломної педагогічної освіти 3 метою проєктування траєкторії власного зростання в умовах змін.

\section{Список використаної літератури}

1. Професійна підготовка майбутнього вчителя: форми і методи. URL: https://osvita.ua/vnz/reports/pedagog/14234/ (дата звернення 22.01.2021).

2. Лист Міністерства освіти і науки України від 11.08.2020 № 1/9-430 «Шодо методичних рекомендацій про викладання навчальних предметів у закладах загальної середньої освіти у 2020/2021 навчальному році». URL: https://mon.gov.ua/ ua/npa/shodo-metodichnih-rekomendacij-pro-vikladannya-navchalnih-predmetiv-u-zakladah-zagalnoyi-serednoyi-osviti-u20202021-navchalnomu-roci (дата звернення: 15.06.2021)

3. Glatthorn A. Teacher development: International Encyclopedia of Teaching and Teacher Education. London: Pergamon Press, 1995. $198 \mathrm{p}$

4. Day S., Sachs J. International Handbook on the Continuing Professional Development of Teachers. 2009. London: Open University Press. 320 p.

5. Day S. Developing Teachers: The Challenge of Lifelong Learning. London: Palmer Press, 1999. 239 p.

6. Семиченко В.А. Психологічні аспекти професійної підготовки і післядипломної освіти педагогічних кадрів. Післядипломна освіта в Украӥні. 2001. № 1. С.54-57.

7. Яцина О.Ф. Самореферентність дискурсивної ідентичності. Проблеми сучасної психології. 2015. Том 30. С.764-775.

8. МОН України. Профстандарт вчителя початкових класів, вчителя закладу загальної середньої освіти і вчителя 3 початкової освіти. URL: https://mon.gov.ua/ua/news/zatverdzheno-profstandart-vchitelya-pochatkovih-klasiv-vchitelyazakladu-zagalnoyi-serednoyi-osviti-i-vchitelya-z-pochatkovoyi-osviti (дата звернення: 15.04.2021)

9. Куриш Г.М., Куриш С.М., Палько Т.В., Пахомова Т.Г., Уруська Л.В. (укл.). Рамка безперервного професійного вдосконалення вчителів. URL: https://ngschoolteacher.wixsite.com/cpdinsett/cpd-framework (дата звернення: 15.04.2021)

10.Химинець В.В. Роль інноваційної освіти у сталому розвитку територіальних еколого-економічних систем. Науковий вісник Ужгородського університету. Серія: Економіка. 2016. Вип. 1 (47). Т.2. С.39-44

\section{References}

1. Profesiina pidhotovka maibutnoho vchytelia: formy i metody. (2020). [Professional training of future teachers: forms and methods] https://osvita.ua/vnz/reports/pedagog/14234. [in Ukrainian]

2. Ministry of Education of Ukraine (2020). Lyst Ministerstva osvity $i$ nauky Ukrainy vid 11.08.2020 № 1/9-430 «Shchodo metodychnykh rekomendatsii pro vykladannia navchalnykh predmetiv u zakladakh zahalnoi serednoi osvity u 2020/2021 navchalnomu rotsi» [Letter of the Ministry of Education and Science of Ukraine dated 11.08.2020 № 1 / 9-430 «On methodological recommendations on teaching subjects in general secondary education institutions in the 2020/2021 academic year»]. https://mon.gov.ua/ua/npa/shodo-metodichnih-rekomendacij-pro-vikladannya-navchalnih-predmetiv-u-zakladahzagalnoyi-serednoyi-osviti-u-20202021-navchalnomu-roci. [in Ukrainian].

3. Glatthorn, A. (1995). Teacher development: International Encyclopedia of Teaching and Teacher Education. Pergamon Press.

4. Day, S., \& Sachs, J. (Eds.). (2009). International Handbook on the Continuing Professional Development of Teachers. Open University Press.

5. Day, S. (1999). Developing Teachers: The Challenge of Lifelong Learning. Palmer Press.

6. Semychenko, V.A. (2001). Psykholohichni aspekty profesiinoi pidhotovky i pisliadyplomnoi osvity pedahohichnykh kadriv [Psychological aspects of professional training and postgraduate education of teachers]. Graduate education in Ukraine, 1, 54-57. [in Ukrainian].

7. Yatsyna, O.F. (2015). Samoreferentnist dyskursyvnoi identychnosti. [Self-referentiality of discursive identity]. Problems of modern psychology, 30, 764-775. [in Ukrainian].

8. Ministry of Education of Ukraine (2020). Profstandart vchytelia pochatkovykh klasiv, vchytelia zakladu zahalnoi serednoi osvity $i$ vchytelia $z$ pochatkovoi osvity [Professional standard of a primary school teacher, a teacher of a general secondary education institution and a primary education teacher]. https://mon.gov.ua/ua/news/zatverdzheno-profstandart-vchitelyapochatkovih-klasiv-vchitelya-zakladu-zagalnoyi-serednoyi-osviti-i-vchitelya-z-pochatkovoyi-osviti [in Ukrainian].

9. Kurysh, H.M., Kurysh, S.M., Palko, T.V., Pakhomova, T.H., \& Uruska, L.V. (Eds.). (2016). Ramka bezperervnoho profesiinoho vdoskonalennia vchyteliv. [Framework for continuous professional development of teachers]. https://ngschoolteacher.wixsite. com/cpdinsett/cpd-framework. [in Ukrainian].

10.Khymynets, V.V. (2016). Rol innovatsiinoi osvity u stalomu rozvytku terytorialnykh ekoloho-ekonomichnykh system. [The role of innovative education in the sustainable development of territorial ecological and economic systems]. Scientific Herald of Uzhhorod University. Series: Yconomics, 1 (47), 9-44. [in Ukrainian]

Стаття надійшла до редакції 02.10.2021 р. Стаття прийнята до друку 07.10.2021 р. 


\title{
Palko Tetiana
}

Candidate of Psychological Science

Associate Professor of the Department of Pedagogy and Psychology

Zakarpattia Institute of Postgraduate Pedagogical Education, Uzhhorod, Ukraine

\section{CONTINUOUS PROFESSIONAL DEVELOPMENT AS A COMPONENT OF TEACHER'S SELF- REFERENCE}

\begin{abstract}
The article deals with the new opportunities for teachers' creative self-realization and self-improvement in the context of educational reform with the application of the Framework for Continuous Professional Development of Teachers. The relevance of this topic is caused by the search for mechanisms of self-reflection, self-actualization, and self-development of the teacher. This is encouraged by the Teacher Framework for Continuing Professional Development, which is a guideline for creating innovative models of professional development of teachers. The purpose of the article is to reveal new opportunities for teachers' creative self-realization and self-improvement in terms of educational reform with the application of the Framework for Continuous Professional Development of Teachers. We have used the analysis of scientific developments and the sources on the problem of continuous professional development of a teacher, psychological and pedagogical, educational and methodological literature, information sources on the problem of research. As a result of the study we have found out that supporting the continuous professional development of teachers using the Framework for Continuing Professional Development of Teachers is an effective tool for reflective analysis and reconstruction of their professional path, and therefore - a necessary condition for professional growth. So, an important component of the roadmap of professional development of the teacher is awareness of the teachers of his her professional role as a facilitator of learning. A motivated teacher, who uses the Framework for Continuing Professional Development, can anticipate and design the trajectory of their growth, success in teaching, opportunities and obstacles to achieving goals The analysis of scientific literature, information sources on the research problem shows that self-reference acquires special significance for teachers of all levels from a novice teacher who has just chosen this profession to a creative professional.

Key words: framework for continuous professional development of teachers; self-reference; descriptor; facilitator; evaluation
\end{abstract}

